\title{
Nitric oxide lacks direct effect on TRPC5 channels but suppresses endogenous TRPC5-containing channels in endothelial cells
}

\author{
Ching-On Wong • Piruthivi Sukumar • David J. Beech • \\ Xiaoqiang Yao
}

Received: 25 November 2009 /Revised: 7 March 2010 /Accepted: 9 March 2010 / Published online: 14 April 2010

(C) Springer-Verlag 2010

\begin{abstract}
TRPC5 is a member of the canonical transient receptor potential (TRPC) family of proteins that forms cationic channels either through homomultimeric assembly or heteromultimeric coordination with other TRPC proteins. It is expressed in a variety of cells including central neurones and endothelial cells and has susceptibility to stimulation by multiple factors. Here we investigated if TRPC5 is sensitive to nitric oxide. Mouse TRPC5 or human TRPC5 was overexpressed in HEK293 cells, and TRPC5 activity was determined by measuring the cytosolic $\mathrm{Ca}^{2+}$ concentration with an indicator dye or by recording membrane current under voltage clamp. TRPC5 activity could be evoked by carbachol acting at muscarinic receptors, lanthanum, or a reducing agent. However, S-nitroso-N-acetylpenicillamine
\end{abstract}

Electronic supplementary material The online version of this article (doi:10.1007/s00424-010-0823-3) contains supplementary material, which is available to authorized users.

Ching-On Wong and Piruthivi Sukumar contributed equally to this work.

C.-O. Wong $\cdot$ X. Yao $(\bowtie)$

Li Ka Shing Insitute of Health Sciences and

School of Biomedical Sciences,

The Chinese University of Hong Kong,

Shatin, Hong Kong, People's Republic of China

email: yao2068@cuhk.edu.hk

P. Sukumar D D. J. Beech $(\bowtie)$

Institute of Membrane and Systems Biology,

Faculty of Biological Sciences, University of Leeds,

Leeds LS2 9JT, UK

e-mail: d.j.beech@leeds.ac.uk
(SNAP) and diethylamine NONOate (DEA-NONOate) failed to stimulate or inhibit TRPC5 at concentrations that generated nitric oxide, caused vasorelaxation, or suppressed activity of TRPC6 via protein kinase G. At high concentrations, SNAP (but not DEA-NONOate) occasionally stimulated TRPC5 but the effect was confounded by background TRPC5-independent $\mathrm{Ca}^{2+}$ signals. Endogenous $\mathrm{Ca}^{2+}$-entry in bovine aortic endothelial cells (BAECs) was suppressed by SNAP; TRPC5 blocking antibody or dominant-negative mutant TRPC5 suppressed this $\mathrm{Ca}^{2+}$ entry and occluded the effect of SNAP. The data suggest that nitric oxide is not a direct modulator of homomeric TRPC5 channels but may inhibit endogenous BAEC channels that contain TRPC5.

Keywords Transient receptor potential · Nitric oxide Nitrovasodilators · Endothelial cell · TRP channels

\section{Introduction}

Nitric oxide (NO) is a short-lived, reactive molecule that serves as an important cellular signal [15]. NO signaling is involved in endothelial-dependent vascular relaxation, cell motility, immune defense, and neurite outgrowth [2, 4, 7]. While many NO-elicited responses are mediated by cGMP, which is produced from the activity of NO-stimulated guanylate cyclase [15], NO can also act independently of cGMP [6]. A well-documented NO action independent of cGMP is S-nitrosylation. In S-nitrosylation, a nitric oxide moiety is covalently attached to cysteine residues of a protein, resulting in alteration in protein function. S- 
nitrosylation serves as a type of posttranslational modification analogous to phosphorylation and acetylation. While some substrate proteins are constitutively S-nitrosylated [8], other proteins can be reversibly S-nitrosylated dependent upon the concentration of $\mathrm{NO}$ and the accessibility of the NO radicals to the cysteine residues [6]. A wide spectrum of proteins including metabolic, structural, and signaling proteins can be S-nitrosylated [6, 8]. S-nitrosylation is reported to modulate the activity of a number of ion channels including $\mathrm{Ca}^{2+}$-activated $\mathrm{K}^{+}$channels, ryanodine receptors, hyperpolarization-activated cation channels, cyclic nucleotide-gate channels, and N-methyl-D-aspartate receptors $[6,8,16]$.

TRPC5 is a $\mathrm{Ca}^{2+}$-permeable cationic channel that modulates properties of mammalian cells including neurones and endothelial cells [1]. It can form channels on its own or assembled with other related proteins such as TRPC1 and TRPC4. Each channel is thought to require four TRPC proteins to assemble around a central ion pore. The channels show constitutive activity and voltage dependence but they are also stimulated by a range of factors including agonists at $\mathrm{G}$ protein-coupled receptors, lysophospholipids, redox factors, and acidification. In addition, it has been suggested that the channels are stimulated by NO through a mechanism that requires direct S-nitrosylation of TRPC5 at two cysteine residues near the ion pore [24]. The effect was suggested to be functionally important in endothelial cells, which have a crucial role in generating NO. However, the conclusions are difficult to reconcile with data suggesting that the same cysteine residues form a disulphide bridge [23] and that NO has commonly been found to be an inhibitor of $\mathrm{Ca}^{2+}$ entry in endothelial cells $[5,11,18,21$, but see 13]. Here, we show data generated independently by our two laboratories that lead us to conclude that $\mathrm{NO}$ is not a direct modulator of TRPC5.

\section{Materials and methods}

\section{Cell culture and cDNA expression}

For single-cell $\mathrm{Ca}^{2+}$ imaging studies, mouse TRPC5 (mTRPC5) in pcDNA3 or human TRPC3 (hTRPC3) in pcDNA6 were stably transfected into HEK293 cells. For experiments with protein kinase $\mathrm{G}$ (PKG) inhibition of TRPC6, PKG- $1 \alpha$ in pcDNA6 and mTRPC6 in pcDNA3 were stably cotransfected into HEK293 cells. mTRPC5 and mouse TRPC6 clones were gifts from L. Birnbaumer (NIH). Transfection and cell culture of HEK293 were done as described elsewhere [12]. Expression of TRPC5 was validated by western blotting (Suppl. Fig. 1). For the multiwell fluorescence plate reader system, HEK293 cells stably expressing tetracycline-inducible human TRPC5
(hTRPC5) was established and cultured as described previously [25]. The expression of hTRPC5 was induced by $1 \mu \mathrm{g} / \mathrm{ml}$ tetracycline (Tet + ) for $24-48 \mathrm{~h}$ before experiments. Noninduced cells without addition of tetracycline (Tet-) were used as control. The primary cultured bovine aortic endothelial cells (BAECs) were isolated from bovine aorta obtained from the local abattoir and using methodology described previously [3]. Briefly, aortic segments were cut open longitudinally. The intima layer was peeled off and then digested with $0.1 \%$ collagenase in phosphatebuffered saline (PBS; in mM: $140 \mathrm{NaCl}, 3 \mathrm{KCl}, 25$ Tris, $\mathrm{pH}$ 7.4) for $15 \mathrm{~min}$ at $37^{\circ} \mathrm{C}$ under vigorous shaking. Dissociated cells were centrifuged, resuspended, and then grown in a culture medium RPMI-1640 supplemented with $10 \%$ fetal bovine serum. Cells of passage 3-12 were used for experiments. In some experiments, BAECs were transfected with pEGFP-N1 or dominant-negative TRPC5 construct (DN-T5) by electroporation (Nucleofector, Lonza Cologne). Transfected cells were seeded on coverslips and cultured for 2 days before experiments. DN-T5 was gift from D. Clapham (Harvard University). All cells were cultured in $95 \%$ air and $5 \% \mathrm{CO}_{2}$.

Intracellular $\mathrm{Ca}^{2+}$-measurement

For single-cell $\mathrm{Ca}^{2+}$ imaging studies, intracellular $\mathrm{Ca}^{2+}$ $\left(\left[\mathrm{Ca}^{2+}\right]_{\mathrm{i}}\right)$ was imaged using the InCyt Basic Im2 live cell system (Intracellular Imaging). For multiwell intracellular $\mathrm{Ca}^{2+}$ measurement studies, intracellular $\mathrm{Ca}^{2+}$ was measured using a fluorescence plate reader system (FlexStation, Molecular Devices). In single-cell $\mathrm{Ca}^{2+}$ imaging experiments, cells seeded on coverslip were loaded with $5 \mu \mathrm{M}$ fura-2 AM in culture medium for $30 \mathrm{~min}$ and then mounted in a recording chamber containing bath solution. Stock solutions of the chemicals were kept on ice during the experiment. At approximately $10 \mathrm{~s}$ before each chemical addition, one tenth of the bath solution was pipetted to dilute the chemical from its stock, before readdition of the solution to the bath. Normal physiological saline solution contained, in $\mathrm{mM}: 140 \mathrm{NaCl}, 5 \mathrm{KCl}, 2$ $\mathrm{MgCl}_{2}, 1 \mathrm{CaCl}_{2}, 10$ glucose, 10 Hepes (pH titrated to 7.4 with $\mathrm{NaOH}$ ). Hepes-buffered saline (HBS) contained in mM: $107 \mathrm{NaCl}, 6 \mathrm{KCl}, 1.2 \mathrm{MgSO}_{4}, 2 \mathrm{CaCl}_{2}, 11.5$ glucose, 20 Hepes ( $\mathrm{pH}$ titrated to 7.4 with $\mathrm{NaOH}$ ). HBS-EGTA contained in mM: $107 \mathrm{NaCl}, 6 \mathrm{KCl}, 1.2 \mathrm{MgSO}_{4}, 0.5$ EGTA, 11.5 glucose, 20 Hepes ( $\mathrm{pH}$ titrated to 7.4 with $\mathrm{NaOH}$ ). For FlexStation experiments, cells were plated in 96-well biocoat plates (Corning) to $80-90 \%$ confluence 24 $48 \mathrm{~h}$ before experiments. Prior to recording, cells were incubated for $1 \mathrm{~h}$ at $37^{\circ} \mathrm{C}$ in standard bath solution (SBS) containing $2 \mu \mathrm{M}$ fura- $2 \mathrm{AM}$ and (in $\mathrm{mM}$ ) $130 \mathrm{NaCl}, 5 \mathrm{KCl}$, 8 glucose, 10 Hepes, $1.2 \mathrm{MgCl}_{2}$, and $1.5 \mathrm{CaCl}_{2}$ (pH titrated to 7.4 with $\mathrm{NaOH}$ ). Subsequently, the cells were washed 
with fresh SBS for $0.5 \mathrm{~h}$ at room temperature. Fura-2 was excited by light at 340 and $380 \mathrm{~nm}$ and emission was filtered at $510 \mathrm{~nm}$. Experiments were at room temperature $\left(\sim 23^{\circ} \mathrm{C}\right)$. Most experiments were performed using fura- 2 as the fluorescent dye, where the $\left[\mathrm{Ca}^{2+}\right]_{i}$ response was expressed as the ratio of the fluorescence signal from excitation at $340 \mathrm{~nm}$ to that at $380 \mathrm{~nm}\left(\mathrm{~F}_{340 / 380}\right)$. Some experiments were done using fluo-3 as the fluorescent dye, where the $\left[\mathrm{Ca}^{2+}\right]_{\mathrm{i}}$ response was expressed as real-time fluo3 fluorescence relative to its initial value before application of chemicals $\left(\mathrm{F}_{\mathrm{t}} / \mathrm{F}_{0}\right)$. In FlexStation experiments, NO donors were diluted in bath solution to five times the final concentration immediately before each experiment and applied to cells at five times dilution by the FlexStation within 5 (column 1) and 30 min (column 2); no difference between data from columns 1 and 2 was observed.

\section{Electrophysiology}

To study hTRPC5, whole-cell patch-clamp recordings were performed as described previously [23]. Patch pipette solution contained (in $\mathrm{mM}$ ): $115 \mathrm{CsCl}, 10 \mathrm{EGTA}, 2 \mathrm{MgCl}_{2}$, $5 \mathrm{Na}_{2} \mathrm{ATP}, 0.1 \mathrm{NaGTP}, 10$ Hepes, $5.7 \mathrm{CaCl}_{2}$ (osmolarity was adjusted to $\sim 290 \mathrm{mOsm}$ with mannitol and $\mathrm{pH}$ was titrated to 7.2 using $\mathrm{CsOH}$ ). The extracellular (bath) solution was SBS. A salt-agar bridge was used to connect the $\mathrm{Ag}-\mathrm{AgCl}$ ground wire to the bath. Signals were amplified with an Axopatch 200B patch-clamp amplifier and controlled with Signal software 3.05 (CED). A 1-s ramp protocol from $-100 \mathrm{mV}$ to $+100 \mathrm{mV}$ was applied at a frequency of $0.1 \mathrm{~Hz}$ from a holding potential of $-60 \mathrm{mV}$. Current signals were analogue filtered (Bessel) at $1 \mathrm{kHz}$ and digitally sampled at $3 \mathrm{kHz}$. NO donors were prepared freshly for each experiment within 1-2 min before application.

\section{Isometric tension measurement}

Segments of mouse aorta $\sim 2 \mathrm{~mm}$ in length were dissected from $\sim 5$-week-old male C57BL/6 mice and the endothelial layer was rubbed off. The segments were mounted in a wire myograph (610 M, Danish Myograph Technology) under a normalized tension as previously described [3]. The aortic segments were preconstricted with $10 \mu \mathrm{M}$ phenylephrine to achieve sustained contractions. Approximately $30 \mathrm{~min}$ before phenylephrine-induced precontraction, dimethyl sulfoxide (DMSO)-diluted NO donors were prepared from stocks into the following concentrations (in $\mathrm{mM}$ ): $0.1,0.3$, 1 , and 300 for SNAP; $0.01,0.1,1,10$, and 100 for diethylamine NONOate (DEA-NONOate). The diluted NO donors were kept on ice and used for a single set of experimental recordings. The NO donors were added in a cumulative fashion to the bath solution, which was Krebs solution containing, in $\mathrm{mM}: 118 \mathrm{NaCl}, 4.7 \mathrm{KCl}, 2.5 \mathrm{CaCl}_{2}$, $1.2 \mathrm{MgSO}_{4}, 1.2 \mathrm{KH}_{2} \mathrm{PO}_{4}, 25.2 \mathrm{NaHCO}_{3}$, and 11.1 glucose, gassed with $95 \% \quad \mathrm{O}_{2}-5 \% \mathrm{CO}_{2}$. Experiments were performed at $37^{\circ} \mathrm{C}$. Data were acquired and analyzed using PowerLab and LabChart (AD Instruments).

Measurement of NO release using multiwell imaging system

HEK293 cells cultured in 96-well plates were loaded with $10 \mu \mathrm{M}$ DAF-FM acetate (Invitrogen, UK) by incubating at room temperature for $45 \mathrm{~min}$. Cells were washed for $20 \mathrm{~min}$ and fluorescence emission at $520 \mathrm{~nm}$ was measured with excitation at $495 \mathrm{~nm}$ by the multiwell fluorescence plate reader system (FlexStation, Molecular Devices). Fluorescence values were divided by 1,000 and indicated as $\mathrm{F}^{*}$.

Immunoblotting

Whole-cell lysates were extracted with detergent extraction buffer, which contained $1 \%(v / v)$ Nonidet P-40, $150 \mathrm{mM}$ $\mathrm{NaCl}, 20 \mathrm{mM}$ Tris-HCl, pH 8.0, or NuPAGE LDS buffer (Invitrogen) with addition of protease inhibitor cocktail tablets. Equal quantities of extracted proteins were applied to each lane and separated on SDS/PAGE gel. The proteins were then blotted onto a PVDF/nitrocellulose membrane. The membrane was incubated at $4{ }^{\circ} \mathrm{C}$ overnight with antiTRPC5 or anti-TRPC6 antibody (dilution 1:200 for Alomone Lab anti-TRPC5 and anti-TRPC6, or dilution 1:500 for custom made T5C3 to peptide CKLLDSSEDV FETWGE) in PBS solution (Invitrogen) containing 0.1\% Tween 20 and 5\% nonfat dry milk. The membrane was washed in PBS + Tween $20(0.1 \%)$ and incubated with horseradish-conjugated secondary antibodies for $1 \mathrm{~h}$. Immunodetection was accomplished by ECL detection system and X-ray film exposure. Immunoblots with anti$\beta$-tubulin antibody or anti- $\beta$-actin (Santa Cruz Biotechnology) were used to confirm that an equal amount of proteins was loaded onto each lane.

\section{Immunodetection of TRPC5 in BAECs}

Immunocytochemical staining of BAECs was done as described previously, with slight modifications [20]. The fixed cells were incubated with or without primary antibodies of rabbit anti-TRPC5 (dilution 1:100, Alomone Lab) and goat antiplatelet endothelial cell adhesion molecule 1 (anti-PECAM1, dilution 1:100, Santa Cruz) at $4^{\circ} \mathrm{C}$ overnight, followed by incubation with secondary donkey antirabbit $\operatorname{IgG}$ conjugated to Alexa Fluor 488 (1:200) and donkey anti-goat $\operatorname{IgG}$ conjugated to Alexa Fluor 546 (1:200). Immunofluorescence was detected by FV1000 confocal system (Olympus). Fluorescence signals were 
acquired at the settings under which the signals from the control cells (without primary antibodies) were absent.

\section{Anti-TRPC5 blocking antibody}

Anti-TRPC5-blocking antibody (T5E3) was raised in rabbits by replicating a previously described strategy [22]. Briefly, a peptide corresponding to TRPC5 putative pore region (CYETRAIDEPNNCKG) was synthesized and conjugated to keyhole limpet hemocyanin at Alpha Diagnostic International. The conjugated T5E3 peptide was injected subcutaneously to the back of a rabbit followed by two booster doses. T5E3 antiserum was collected 4 weeks after the second booster. $\operatorname{IgG}$ was purified from T5E3 antiserum and preimmune serum using a protein $\mathrm{G}$ column. Antibodies were applied to the cells at $4 \mu \mathrm{g} / \mathrm{ml}$.

\section{Chemicals and reagents}

Carbachol (Calbiochem), $\mathrm{LaCl}_{3}$ (Sigma), and adenosine triphosphate sodium salt (ATP; Sigma) were prepared as $100 \mathrm{mM}$ stock solutions in $\mathrm{H}_{2} \mathrm{O}$. 1-oleoyl-2-acetyl-snglycerol (OAG; Calbiochem), KT5823 (Calbiochem), ODQ (Calbiochem), 8-bromo-cGMP (Calbiochem), and 2aminoethoxydiphenyl borate (2-APB; Calbiochem) solution were prepared in DMSO. SNAP (Sigma) was prepared as a $300-$ or $250-\mathrm{mM}$ stock dissolved in DMSO, and the aliquots were stored at $-20^{\circ} \mathrm{C}$. DEA-NONOate (Cayman) was prepared as a $100-$ or $30-\mathrm{mM}$ stock dissolved in ethanol or DMSO, and the aliquots were stored at $-80^{\circ} \mathrm{C}$.

\section{Data analysis and presentation}

Data from $\mathrm{Ca}^{2+}$-imaging were plotted as traces and expressed as mean \pm SEM of cells/wells in one experiment. Traces from patch-clamp recording and arterial tension measurement are representative individual experiments. Bar charts show data in mean \pm SEM of all or combined experiments. Number of individual recordings " $\mathrm{n}$ " is given in parenthesis. Student's $t$ test was used for statistical comparison, with probability $p<0.05$ (single asterisk) or $p<0.01$ (double asterisks) as a significant difference.

\section{Results}

Lack of effect of NO donors on $\mathrm{Ca}^{2+}$-influx mediated by TRPC 5

In single-cell intracellular $\mathrm{Ca}^{2+}$ measurement studies of mTRPC5, cells were exposed to a high concentration of SNAP $(300 \mu \mathrm{M})$. In 18 out of 23 independent experiments, SNAP failed to elicit a significant response (e.g., Fig. 1a).
In the other five experiments, SNAP elicited a small rise in $\left[\mathrm{Ca}^{2+}\right]_{\mathrm{i}}$ but this effect was not unique to the TRPC5expressing cells, occurring also in the vector control group (Suppl. Fig. 2). Addition of carbachol (CCh), which acts as an agonist at endogenous muscarinic receptors, caused marked elevation of $\left[\mathrm{Ca}^{2+}\right]_{i}$ in TRPC5-expressing cells (Fig. 1a) due to $\mathrm{IP}_{3}$-sensitive store $\mathrm{Ca}^{2+}$ release and receptor-mediated activation of TRPC5 [14]. Lanthanum $\left(\mathrm{La}^{3+}\right)$, which stabilizes the open state of TRPC5 channels [10], enhanced the $\mathrm{Ca}^{2+}$ signal and 2-APB, which blocks TRPC5 channels [21], suppressed the signal (Fig. 1a). In vector-transfected cells, CCh elicited a small transient rise in $\left[\mathrm{Ca}^{2+}\right]_{i}$, which is due to TRPC5-independent $\mathrm{Ca}^{2+}$ release, and $\mathrm{La}^{3+}$ had no effect (Fig. 1b, c). Analysis of data from all experiments indicated no significant difference between SNAP responses in TRPC5- and vectortransfected cells (Fig. 1c). The data suggest that mTRPC5 is stimulated by $\mathrm{CCh}$ and $\mathrm{La}^{3+}$ but not by SNAP.

Multiwell intracellular $\mathrm{Ca}^{2+}$ measurement studies of hTRPC5 revealed similar insensitivity to SNAP, with $100 \mu \mathrm{M}$ SNAP eliciting no rise in $\left[\mathrm{Ca}^{2+}\right]_{\mathrm{i}}$. High concentrations of SNAP $(250$ or $500 \mu \mathrm{M})$ elicited a $\left[\mathrm{Ca}^{2+}\right]_{\mathrm{i}}$ rise in some batches of hTRPC5-expressing cells but these concentrations also had effects in control cells (Fig. 1d, e). Comprehensive presentation of all individual data sets is shown in Suppl. Fig. 3, indicating that there was modest hTRPC5 stimulation by 250 or $500 \mu \mathrm{M}$ SNAP in some recordings. However, statistical analysis of all data did not support a conclusion that hTRPC 5 could be stimulated by any SNAP concentration $(1-500 \mu \mathrm{M})$ on a reliable basis (Fig. 1f). Strong $\left[\mathrm{Ca}^{2+}\right]_{\mathrm{i}}$ responses on addition of the lanthanide gadolinium $\left(\mathrm{Gd}^{3+}\right)$ confirmed that there was functional expression of TRPC5 in Tet + but not Tet(control) cells (Fig. 1d-f). Concentration-response data for $\mathrm{Gd}^{3+}$ established that the recording technique conferred the expected sensitivity (data not shown).

A chemically distinct NO donor, DEA-NONOate, was also tested using the single-cell (mTRPC5) and multiwell (hTRPC5) $\mathrm{Ca}^{2+}$ measurement systems. DEA-NONOate, at a range of concentrations from 10 to $100 \mu \mathrm{M}$, failed to elicit $\left[\mathrm{Ca}^{2+}\right]_{\mathrm{i}}$ rise in mTRPC5-expressing cells (Fig. 2a, c). Similarly, 1 to $150 \mu \mathrm{M}$ DEA-NONOate elicited no response in cells expressing hTRPC5 and responding to $\mathrm{Gd}^{3+}$ (Fig. 2b, c). Preincubation with 10-100 $\mu \mathrm{M}$ DEANONOate did not affect $\mathrm{Gd}^{3+}$ responses (Fig. 2d).

Lack of effect on ionic current mediated by TRPC5

Whole-cell currents were measured from hTRPC5expressing HEK293 (Tet + ) cells using a voltage-ramp protocol (Fig. 3). Spontaneously active TRPC5-mediated currents occurred, as shown by the example time-series relationship for +80 and $-80 \mathrm{mV}$ (Fig. 3a) and current- 


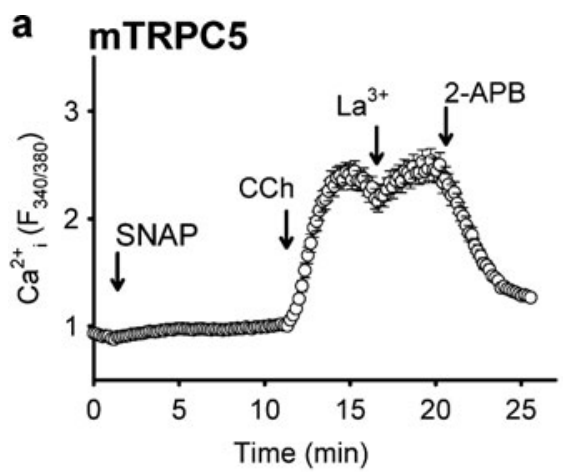

d

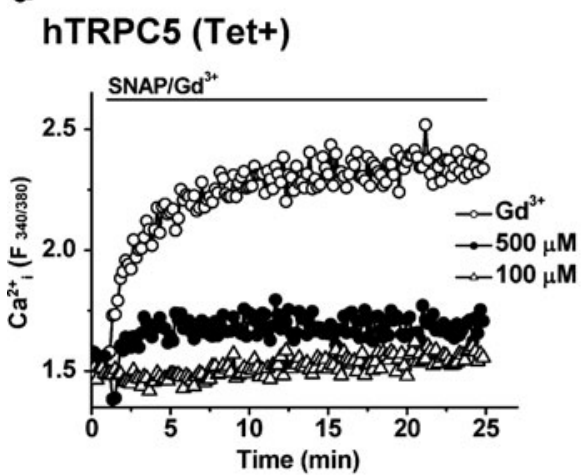

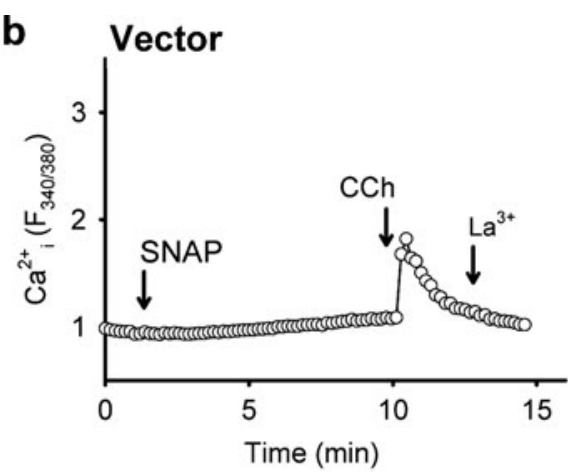

e

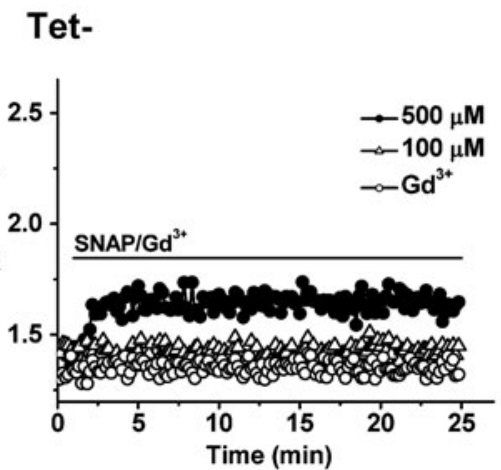

C

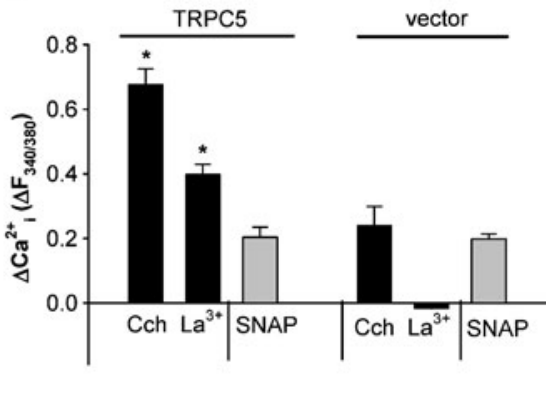

f

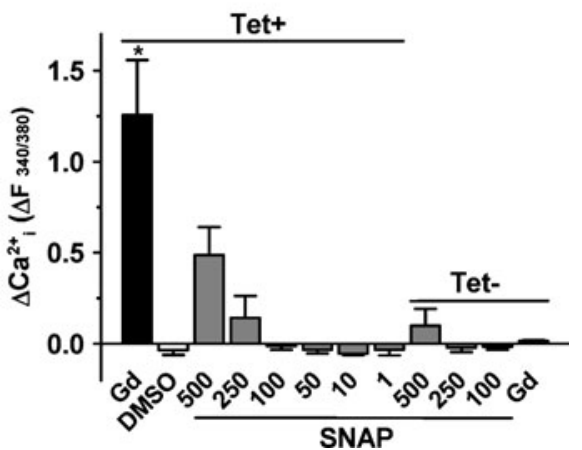

Fig. 1 SNAP on TRPC5-dependent $\mathrm{Ca}^{2+}$-entry in HEK293 cells. a-c mTRPC5 single-cell $\mathrm{Ca}^{2+}$ data. a, b Representative time-series graphs for $\left[\mathrm{Ca}^{2+}\right]_{\mathrm{i}}$ in vector-transfected (b) and mTRPC5-transfected HEK293 cells (a). The bath solution contained NPSS. Arrows indicate the time points when chemicals were added (SNAP, $300 \mu \mathrm{M}$; carbachol $100 \mu \mathrm{M} ; \mathrm{LaCl}_{3} 100 \mu \mathrm{M} ; 2$-APB, $\left.75 \mu \mathrm{M}\right)$. Each trace represents the mean \pm SEM for $\geq 20$ cells. c Mean \pm SEM data for the $\left[\mathrm{Ca}^{2+}\right]_{i}$ response 1 min after application of $\mathrm{CCh}$ or the maximal $\left[\mathrm{Ca}^{2+}\right]_{\mathrm{i}}$ response to $\mathrm{La}^{3+}$ and SNAP, as illustrated in a and b. Each bar

voltage relationship (I-V; Fig. 3b), which is typical of TRPC5 [14, 23, 25]. Bath application of $150 \mu \mathrm{M}$ DEANONOate failed to stimulate or inhibit the current (Fig. 3a, b). In contrast, the reducing agents dithiothreitol or reduced thioredoxin elicited characteristic TRPC5 currents (Fig. 3a-d), as reported previously [23]. Neither DEA-NONOate nor SNAP had significant effects on the TRPC5 currents (Fig. 3d). The data further suggest that TRPC5 is resistant to NO.

Effectiveness of $\mathrm{NO}$ donors to deliver $\mathrm{NO}$ in experiments

As positive controls for the NO donors, we first performed isometric contraction studies on mouse aortic segments where NO donors are known to act as potent vasorelaxants [9]. SNAP elicited relaxation of tone at $0.1-1 \mu \mathrm{M}$ concentrations, while DEA-NONOate elicited relaxations at 10 and $100 \mu \mathrm{M}$ concentrations (Fig. 4a, b). Treatment of HEK293 cells with these two NO donors also caused substantial elevation of intracellular NO as monitored by the NO-sensitive fluorescence dye DAF-FM acetate (Fig. 4c-f). As shown, extracel- represents the mean value from seven independent experiments. $\mathbf{d}-\mathbf{f}$ hTRPC5 multiwell $\mathrm{Ca}^{2+}$ data. Shown are representative time-series graphs for $\left[\mathrm{Ca}^{2+}\right]_{\mathrm{i}}$ in response to SNAP $(100 \mu \mathrm{M}, 500 \mu \mathrm{M})$, DMSO $(0.2 \%)$, and $\mathrm{Gd}^{3+}(100 \mu \mathrm{M})$ in HEK293 cells stably expressing hTRPC5 under a tetracycline-inducible promoter with (Tet+; d) and without tetracycline (Tet-; e) induction. The data points represent the mean for $\geq 3$ wells (SEM bars have been omitted for clarity; for full data sets see Suppl. Fig. 3). f Mean $\pm \operatorname{SEM}(n=3)$ data for the maximal $\left[\mathrm{Ca}^{2+}\right]_{\mathrm{i}}$ change evoked by the applied chemicals

lular application of $100 \mu \mathrm{M}$ SNAP (Fig. 4c, e) or $90 \mu \mathrm{M}$ DEA-NONOate (Fig. 4d, f) increased the intracellular NO level in a time-dependent manner. We also tested the biological activity of SNAP and DEA-NONOate through their expected inhibitory effects on TRPC6. TRPC6 and TRPC3 are two TRPC isoforms that were previously reported to be inhibited by NO-cGMP-PKG pathway [12, 18]. Application of the TRPC6 activator OAG induced a $\left[\mathrm{Ca}^{2+}\right]_{\mathrm{i}}$ rise in TRPC6-expressing HEK293 cells (Fig. 4g). This $\left[\mathrm{Ca}^{2+}\right]_{\mathrm{i}}$ rise was attenuated by a PKG activator 8 -bromocGMP and enhanced by a PKG inhibitor KT5823 or ODQ, a guanylate cyclase inhibitor (Fig. 4h). Importantly, $300 \mu \mathrm{M}$ SNAP or $100 \mu \mathrm{M}$ DEA-NONOate attenuated the OAG-induced $\left[\mathrm{Ca}^{2+}\right]_{\mathrm{i}}$ rise in these cells (Fig. $4 \mathrm{~g}, \mathrm{~h}$ ). The inhibitory effect of DEA-NONOate was reversed by KT5823 (Fig. 4g, h). These results confirmed that SNAP and DEANONOate applied in our systems could effectively release NO to inhibit TRPC6 via NO-cGMP-PKG pathway $[12,18]$.

Collectively, these experiments demonstrate that the NO donors used in our experiments were able to efficiently deliver biologically active NO. 
Fig. 2 DEA-NONOate on TRPC5-dependent $\mathrm{Ca}^{2+}$-entry. a, b Representative time-series graphs for $\left[\mathrm{Ca}^{2+}\right]_{\mathrm{i}}$ in mTRPC5expressing HEK293 cells in response to DEA-NONOate $(100 \mu \mathrm{M})(\mathbf{a}$ the data points represents the mean \pm SEM for $\geq 20$ cells in single-cell $\mathrm{Ca}^{2+}$ measurement, final vehicle concentration of $0.1 \%$ DMSO) and in hTRPC5-expressing HEK293 cells (b the data points represent the mean \pm SEM for $\geq 3$ wells in multiwell $\mathrm{Ca}^{2+}$ measurement). c Mean \pm SEM $(n \geq 3)$ data for the maximal $\left[\mathrm{Ca}^{2+}\right]_{\mathrm{i}}$ change in response to DEA-NONOate as in $\mathbf{a}(n=8)$ and $\mathbf{b}(n=3)$. $\mathbf{d}$ Representative time-series graphs for $\left[\mathrm{Ca}^{2+}\right]_{\mathrm{i}}$ in hTRPC5expressing HEK293 cells in response to $\mathrm{Gd}^{3+}$ after DEANONOate. Carbachol (CCh), $100 \mu \mathrm{M} ; \mathrm{LaCl}_{3}\left(\mathrm{La}^{3+}\right), 100 \mu \mathrm{M}$; $\mathrm{GdCl}_{3}\left(\mathrm{Gd}^{3+}\right), 100 \mu \mathrm{M}$; and DEANONOate (DEA), as indicated $(\mu \mathrm{M}) ; 1 \%$ DMSO in b and $\mathbf{d}$ a
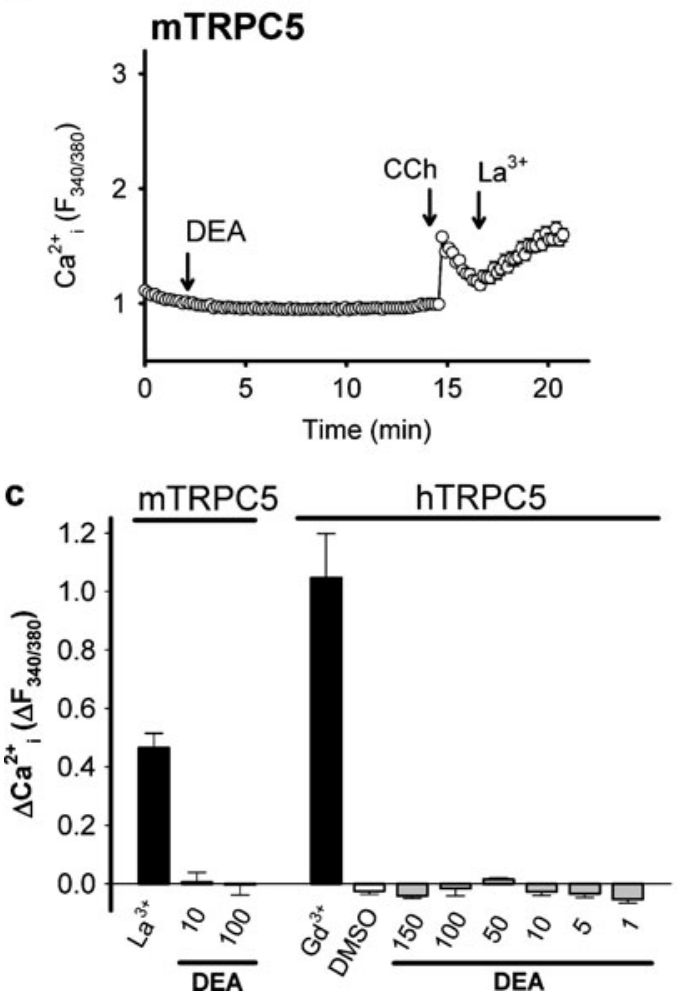

b hTRPC5 (Tet+)

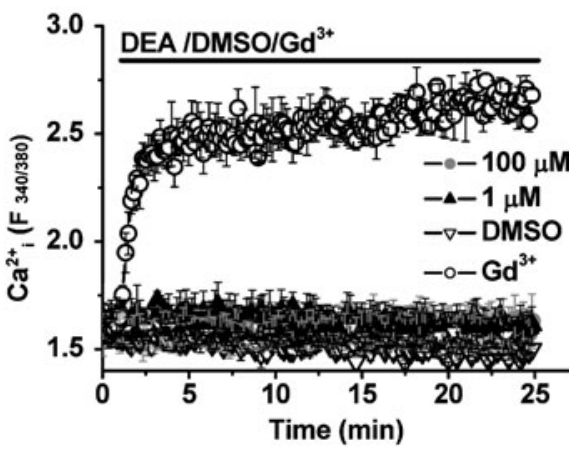

d

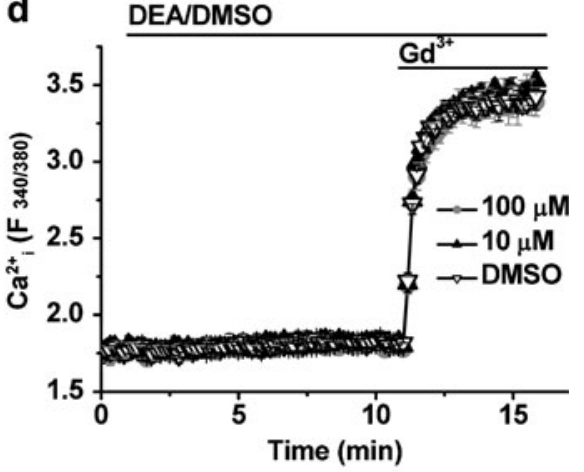

Inhibition of $\mathrm{Ca}^{2+}$-entry in endothelial cells (BAECs)

Resistance of TRPC5 to NO in our experiments but sensitivity in studies of other investigators [24] may have arisen because NO does not act directly but requires an intermediate protein that is inadequately expressed in our
HEK293 cells relative to TRPC5. The identity of such an intermediate is unknown and so we sought to address the possibility by studying an endogenous $\mathrm{Ca}^{2+}$-entry signal that involves TRPC5. The previous reports suggested that TRPC5 is expressed in BAECs and is functionally important in agonist-stimulated $\mathrm{Ca}^{2+}$-entry and spontaneous
Fig. 3 Ionic current through TRPC5 channels during wholecell voltage clamp. Recordings were from HEK293 cells expressing hTRPC5. a Representative time course of whole-cell current sampled at $+80 \mathrm{mV}$ and $-80 \mathrm{mV}$ during a voltage ramp and showing bath application of $150 \mu \mathrm{M}$ DEA-NONOate and $10 \mathrm{mM}$ DTT. b, c Current-voltage relationships (I-Vs) for the experiment in a showing the initial (basal) current and the current in the presence of DEA-NONOate (b), and the current in the presence of DEANONOate and the current induced by DTT $(\mathbf{c})$. d Mean change $(\Delta)$ in inward current at $-80 \mathrm{mV}$ after application of $150 \mu \mathrm{M}$ DEANONOate, $10 \mathrm{mM}$ DTT, $500 \mu \mathrm{M}$ SNAP (10 min) or $4 \mu \mathrm{g} / \mathrm{ml}$ rTRX (5 $\min ; n \geq 3$ ) a
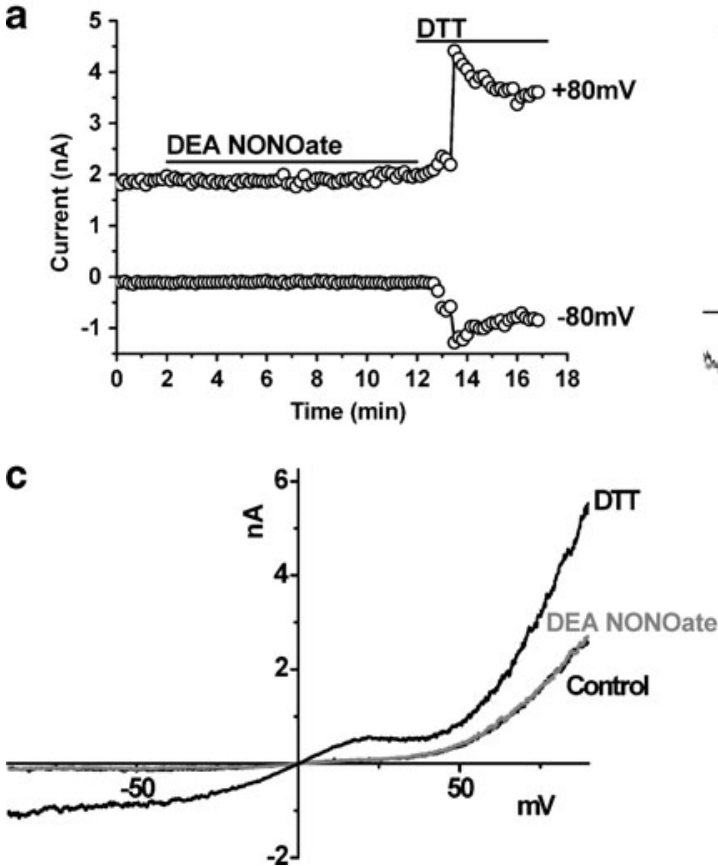

b
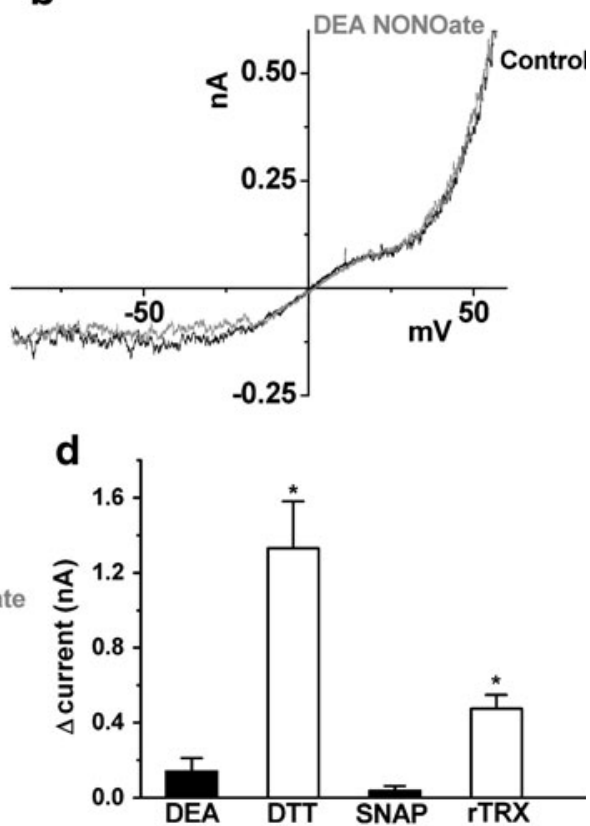
a

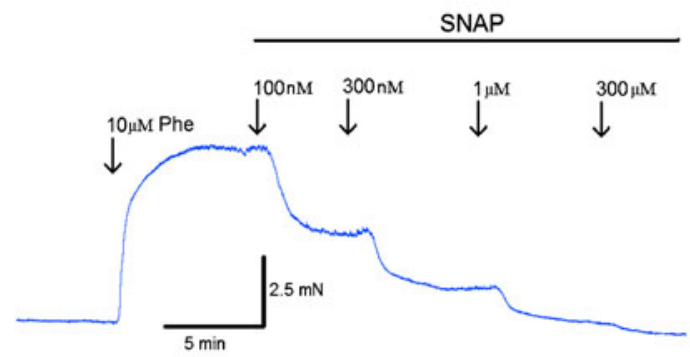

C

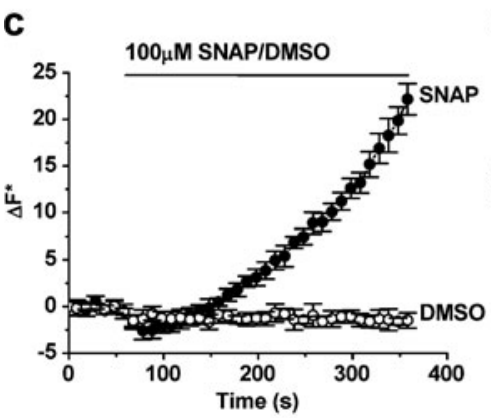

d

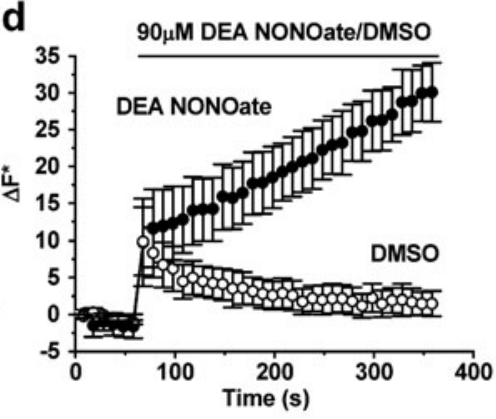

h
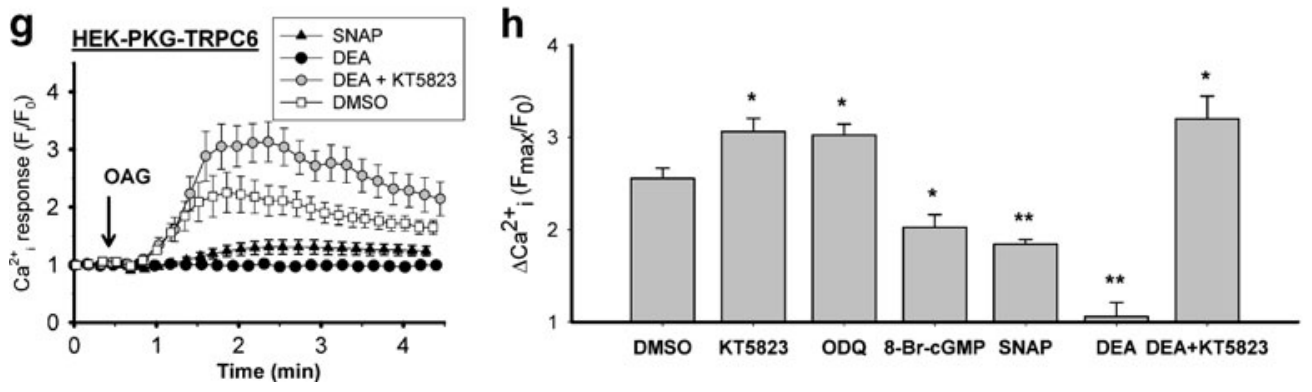

DEA NONO-ate

b

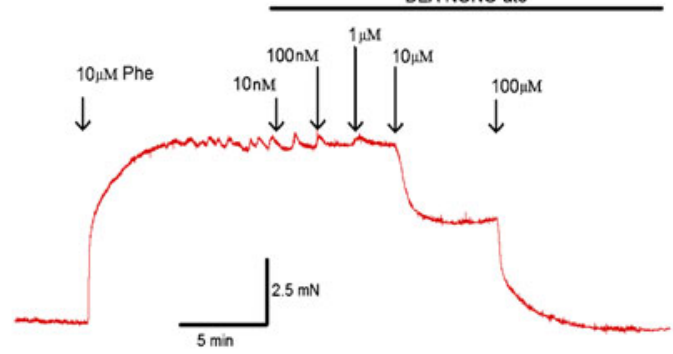

e
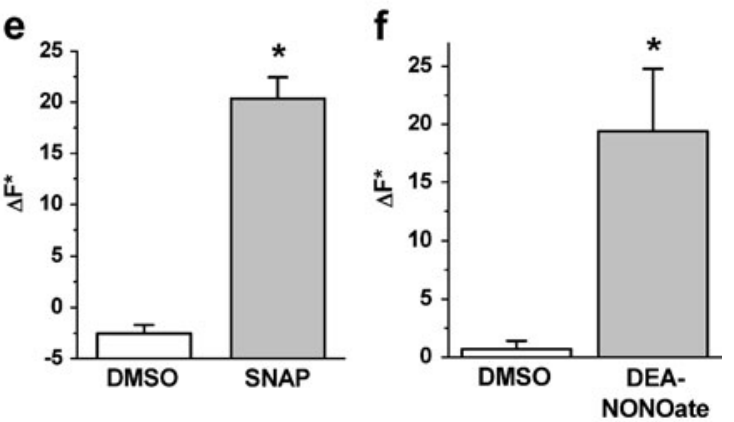

Fig. 4 Validation of NO-releasing capacities of SNAP and DEANONOate. a, b Representative time courses of isometric tension in isolated mouse aortic segments in response to cumulatively increasing concentrations of SNAP (a) and DEA-NONOate (b) applied to the bath. The vessels were denuded of the endothelial layer and preconstricted with $10 \mu \mathrm{M}$ phenylephrine $(P h e ; n=4)$. c, d Representative time-series graphs for change of DAF-FM fluorescence $\left(\Delta \mathrm{F}^{*}\right)$ in HEK293 cells in response to SNAP $(100 \mu \mathrm{M}$, c) or DEA-NONOate $(90 \mu \mathrm{M}, \mathbf{d})$. Also shown are responses to vehicle (DMSO, $0.2 \%$ in $\mathbf{c}$; DMSO, $1.5 \%$ in d). Each data point represents mean \pm SEM for measurements from four wells of a 96-well plate. e, f For three independent experiments, mean \pm SEM data for the maximal $\Delta \mathrm{F}^{*}$ in

$\mathrm{Ca}^{2+}$-entry in these cells $[20,24]$. Figure 5 a showed that TRPC5 immunoreactive signals could be detected in PECAM-1 (an endothelial cell marker)-positive BAECs. Many research groups have investigated the effect of NO on endothelial cell $\left[\mathrm{Ca}^{2+}\right]_{i}$ signaling, While most reports showed an inhibitory action of $\mathrm{NO}$ on $\left[\mathrm{Ca}^{2+}\right]_{\mathrm{i}}$ in endothelial cells $[5,11,18,21]$, there were also a few reports showing stimulatory action of NO donor SNAP on $\left[\mathrm{Ca}^{2+}\right]_{i}$ in endothelial cells $[13,24]$. In our studies, direct application of 10 and $300 \mu \mathrm{M}$ SNAP to cultured BAECs did not cause significant change in $\left[\mathrm{Ca}^{2+}\right]_{\mathrm{i}}$ level $(n=4)$.

We then used a TRPC5-specific blocking antibody T5E3 [22] to investigate the TRPC5 component in the agoniststimulated $\mathrm{Ca}^{2+}$-entry and spontaneous $\mathrm{Ca}^{2+}$-entry. Effec- response to SNAP (e) or DEA-NONOate (f) as in $\mathbf{c}$ and $\mathbf{d}$. $\mathbf{g}$ Representative time-series traces $(n \geq 6)$ for $\left[\mathrm{Ca}^{2+}\right]_{\mathrm{i}}$ in response to $100 \mu \mathrm{M}$ OAG in HEK293 cells cotransfected with PKG1 $\alpha$ and mTRPC6. Prior to OAG addition, cells were pretreated for $5 \mathrm{~min}$ with $0.1 \%$ DMSO, $300 \mu \mathrm{M}$ SNAP, $100 \mu \mathrm{M}$ DEA-NONOate (DEA), or $100 \mu \mathrm{M}$ DEA-NONOate plus $1 \mu \mathrm{M}$ KT5823 (DEA+KT5823). The data points represent the mean \pm SEM for $\geq 20$ cells in a single experiment. h Summary of data showing maximal $\left[\mathrm{Ca}^{2+}\right]_{\mathrm{i}}$ response $\left(\mathrm{F}_{\max } / \mathrm{F}_{0}\right)$ to OAG $(100 \mu \mathrm{M})$ challenge under different pretreatments for 5 min. DMSO, 0.1\%; KT5823, $1 \mu \mathrm{M}$; ODQ, $50 \mu \mathrm{M}$; 8-bromocGMP, $2 \mathrm{mM}$; SNAP, $300 \mu \mathrm{M}$; and DEA-NONOate (DEA), $100 \mu \mathrm{M}$. Mean \pm SEM $(n \geq 6$ experiments)

tiveness of T5E3 as an inhibitor of TRPC5 was confirmed in HEK293 cells over-expressing mTRPC5 (Fig. 5b and Suppl. Fig. 4). T5E3 inhibited the $\mathrm{La}^{3+}$ and carbacholstimulated $\mathrm{Ca}^{2+}$ influx in these cells (Fig. 5b and Suppl. Fig. 4). Specificity of T5E3 was shown through lack of effect of T5E3 on OAG-stimulated $\left[\mathrm{Ca}^{2+}\right]_{\mathrm{i}}$ rises in HEK293 cells over-expressing TRPC3 (Fig. 5c and Suppl. Fig. 4).

ATP stimulates TRPC5 activity via a receptor-operated pathway in BAECs and other cell types [1,24]. We exposed the BAECs to anti-TRPC5 blocking antibody, T5E3, or its control preimmune antibody (Fig. 5d-f). T5E3 suppressed the ATP-stimulated $\mathrm{Ca}^{2+}$-entry (Fig. 5d-f) and ATPstimulated whole-cell current (Suppl. Fig. 6), consistent with TRPC5 having a role in the response. The NO donor SNAP 

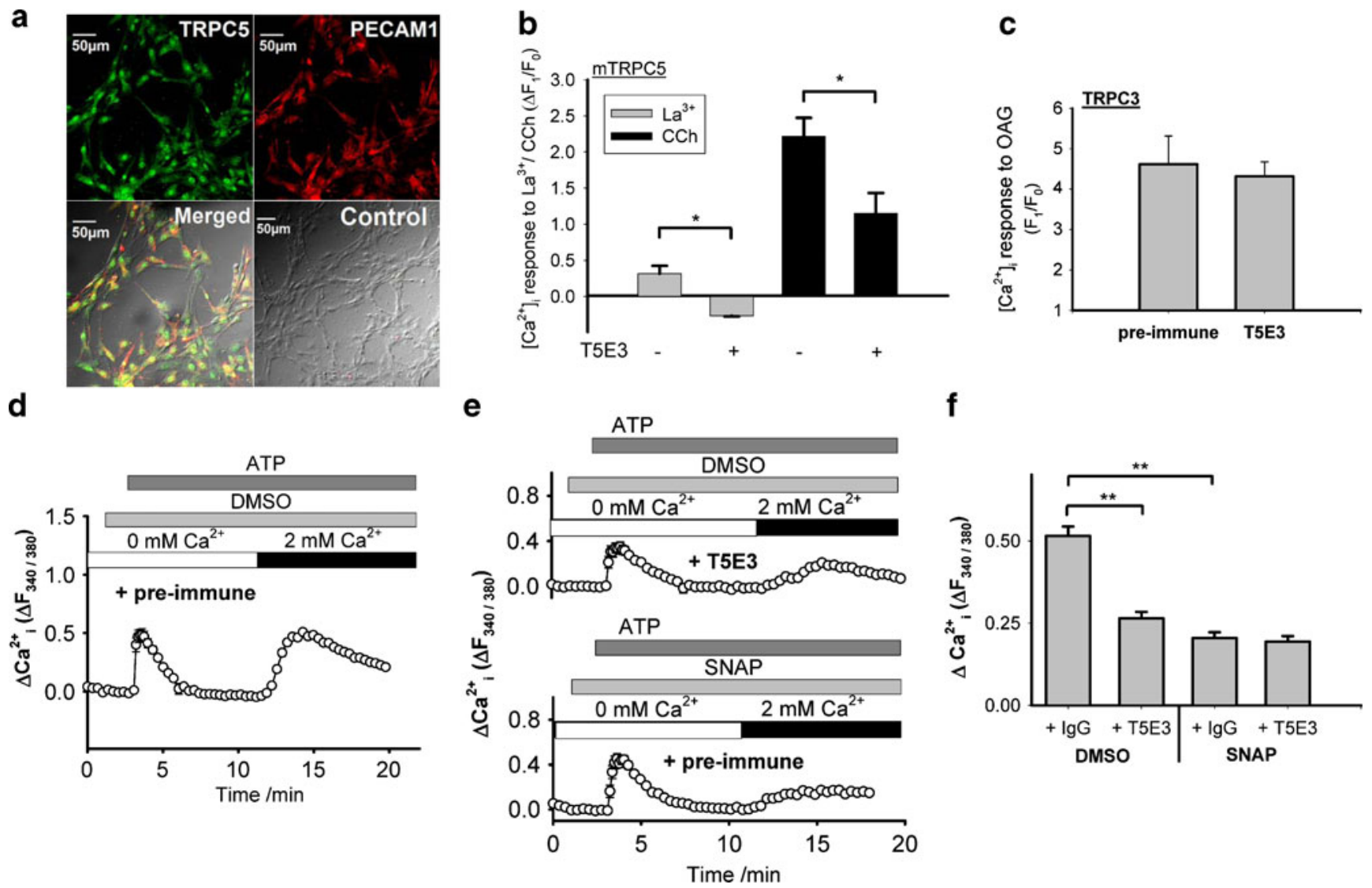

\section{f}

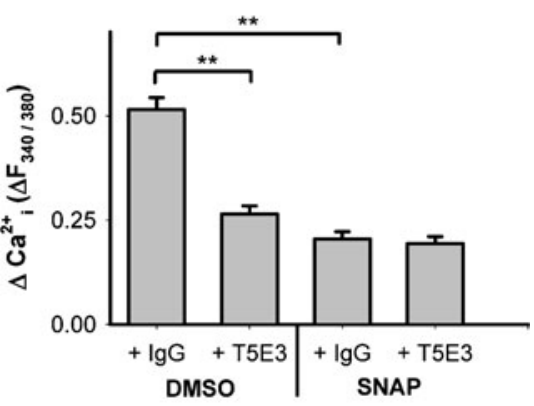

Fig. 5 Endogenous TRPC5 expression in BAECs and inhibitory effect of SNAP on ATP-stimulated $\mathrm{Ca}^{2+}$-entry involving TRPC5. a Immunocytochemical detection of TRPC5 in BAECs. The cells were stained with primary antibodies targeted to TRPC5 (TRPC5; green signals) and to platelet endothelial cell adhesion molecule 1 (PECAM1; red signals). Also shown were the merged fluorescent signals overlaid on the bright-view image (Merged). The control image was the merged image from sample with the omission of primary antibodies (Control). b Inhibitory effect of $\mathrm{T} 5 \mathrm{E} 3$ on $\mathrm{LaCl}_{3}$ $\left(\mathrm{La}^{3+}, 100 \mu \mathrm{M}\right)$ and carbachol $(\mathrm{CCh}, 100 \mu \mathrm{M})$-induced $\left[\mathrm{Ca}^{2+}\right]_{\mathrm{i}}$ rises in mTRPC5-over-expressing HEK293 cells with or without $4 \mu \mathrm{g} / \mathrm{ml}$ antiTRPC5 blocking antibody (T5E3) in the bath solution. Mean \pm SEM $(n=3)$ data are shown $\left({ }^{*} p<0.05\right)$. Representative experimental traces are given in Supplementary Fig. 4. c OAG $(100 \mu \mathrm{M})$-induced $\left[\mathrm{Ca}^{2+}\right]_{\mathrm{i}}$ rises in TRPC3-over-expressing HEK293 cells with $4 \mu \mathrm{g} / \mathrm{ml}$ preimmune $\operatorname{IgG}$ or T5E3 in the bath solution. Mean \pm SEM $(n=3)$ data are

was tested against the $\mathrm{Ca}^{2+}$-entry and was found to be inhibitory (Fig. 5d-f). Furthermore, in T5E3-treated cells, SNAP generated no further inhibition (column 2 and 4 in Fig. 5f); in addition, T5E3 had no further inhibition in the presence of SNAP (column 3 and 4 in Fig. 5f), suggesting that SNAP and T5E3 inhibited the same component.

To study spontaneous $\mathrm{Ca}^{2+}$-entry in BAECs, we first exposed the BAECs to $\mathrm{Ca}^{2+}$-free physiological medium, and then reintroduced $2 \mathrm{mM}$ extracellular $\mathrm{Ca}^{2+}$. $\mathrm{Ca}^{2+}$-entry was observed (Fig. 6a, c). This $\mathrm{Ca}^{2+}$-entry was again suppressed by T5E3 and SNAP (Fig. 6a-c). We also used a dominantnegative TRPC5 construct (DN-T5) that can disrupt TRPC5 function [17]. Expression of DN-T5 also reduced the

shown $(* p<0.05)$. Representative experimental traces are given in Supplementary Fig. 4. d, e Representative time courses of $\left[\mathrm{Ca}^{2+}\right]$ changes in BAECs in response to ATP $(100 \mu \mathrm{M})$. BAECs were bathed in HBS containing $4 \mu \mathrm{g} / \mathrm{ml}$ T5E3 (upper trace of e) or preimmune $\operatorname{IgG}(\mathbf{d}$, lower trace of e) for 20-30 min at room temperature prior to $\mathrm{Ca}^{2+}$ imaging. Bath solution was changed to HBS-EGTA containing preimmune IgG or T5E3 at the beginning of each recording. $300 \mu \mathrm{M}$ SNAP (lower trace of $\mathbf{e}$ ) or $0.1 \%$ DMSO (d, upper trace of $\mathbf{e}$ ) was added to the bath, followed by addition of ATP to elicit store-release. After ATP-addition ( $8 \mathrm{~min}$ ), the $\mathrm{Ca}^{2+}$ influx was initiated by changing the bath solution to HBS containing ATP, DMSO/SNAP with T5E3/ preimmune $\mathrm{IgG}$. Each trace represents the mean \pm SEM of $\geq 10$ cells in one representative experiment. f Summary of data for all independent experiments of the type shown in $\mathbf{d}$ and $\mathbf{e}$, showing the maximal $\left[\mathrm{Ca}^{2+}\right]_{\mathrm{i}}$ change after restoring $\mathrm{Ca}^{2+}$ in bath $(n=6-10$; $* * p<0.01)$

spontaneous $\mathrm{Ca}^{2+}$-entry in BAECs (Fig. 6d-f), supporting involvement of channels that can incorporate TRPC5. Moreover, SNAP inhibited the same component as T5E3 and DN-T5 did (Fig. 6c, f). Taken together, the data suggest that an endogenous $\mathrm{Ca}^{2+}$-entry mechanism involving TRPC5 in endothelial cells is sensitive to inhibition by NO.

\section{Discussion}

In the present study, we found that $\mathrm{NO}$ donors fail to modulate activity of mTRPC5 or hTRPC5 channels exogenously expressed in HEK293 cells when applied at 
a

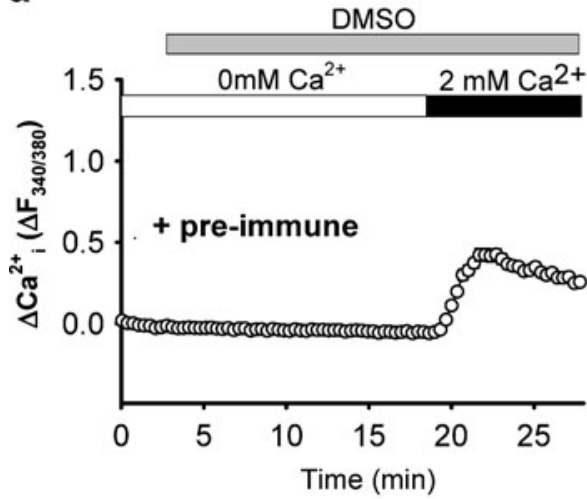

d

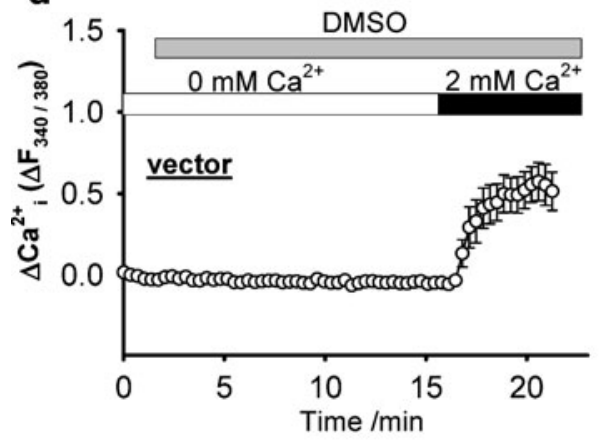

b

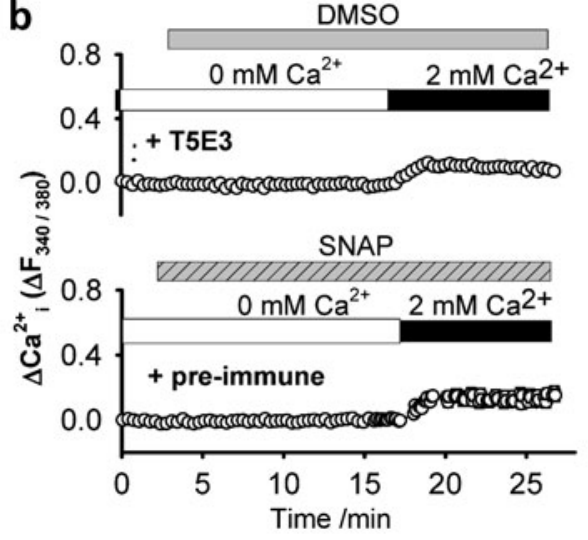

e

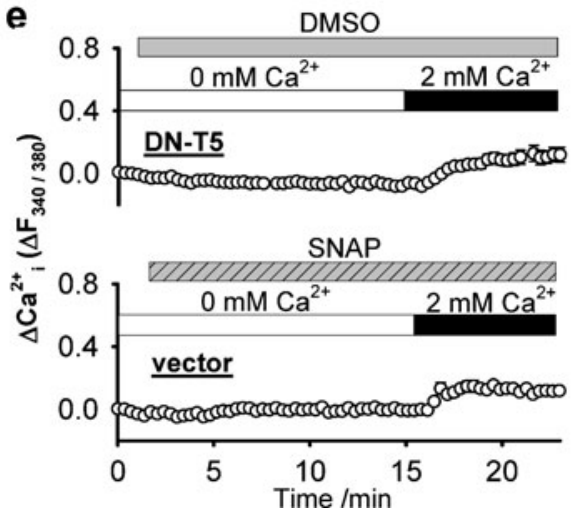

C

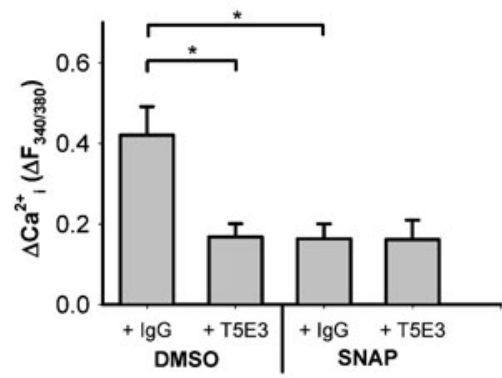

f

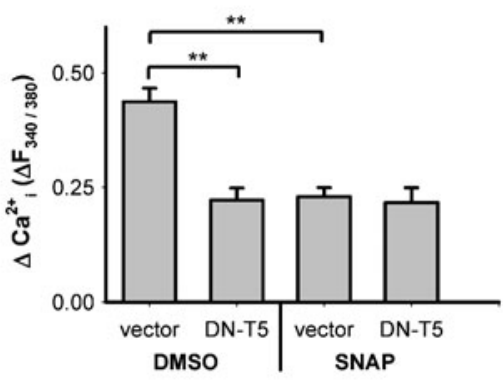

Fig. 6 Inhibitory effect of SNAP on spontaneous $\mathrm{Ca}^{2+}$-entry involving TRPC5 in BAECs. a, b, d, e Representative time courses of $\left[\mathrm{Ca}^{2+}\right]_{i}$ changes in BAECs in response to extracellular $\mathrm{Ca}^{2+}$ readdition. a, b Cells were incubated in HBS containing $4 \mu \mathrm{g} / \mathrm{ml}$ T5E3 (upper trace of $\mathbf{b}$ ) or preimmune $\operatorname{IgG}(\mathbf{a}$, lower trace of $\mathbf{b})$ for 20-30 min prior to $\mathrm{Ca}^{2+}$ imaging. d, e Cells were transfected with empty expression vector (vector) or DN-T5 construct (DN-T5). $300 \mu \mathrm{M}$ SNAP (lower trace of $\mathbf{b}$ and $\mathbf{e}$ ) or $0.1 \%$ DMSO (a and d,

concentrations that are sufficient for generation of NO, evoke vascular relaxation, or suppress TRPC6 via protein kinase G. We did, however, find an inhibitory effect on an endothelial $\mathrm{Ca}^{2+}$-entry mechanism that involved TRPC5. The data suggest that $\mathrm{NO}$ is not a direct modulator of TRPC5 but that it can negatively modulate endogenous TRPC5containing channels through an indirect mechanism.

We occasionally observed a stimulatory effect of SNAP that appeared greater than the response in control cells (Fig. 1f, Suppl. Fig. 3). Although these latter results did not achieve statistical significance, underlying examples (Suppl. Fig. 3) are reminiscent of the results of Yoshida et al. [24]. Therefore, we believe that TRPC5 may be stimulated by SNAP under some conditions but we suggest that any such effect is not due to an action of nitric oxide and occurs only at higher concentrations of SNAP than are necessary to evoke nitric oxide-dependent effects. High concentrations of SNAP may generate free radicals [19], which Yoshida et al. [24] also suggested activate TRPC5. We did not observe any effects of DEA-NONOate. upper trace of $\mathbf{b}$ and $\mathbf{e}$ ) was added to the bath for $15 \mathrm{~min}$, followed by changing the bath solution to HBS DMSO/SNAP with T5E3/ preimmune $\mathrm{IgG}$. Each trace represents the mean $\pm \mathrm{SEM}$ of $\geq 5$ cells in one representative experiment. c, f Summary of data for all independent experiments of the type shown in $\mathbf{a}, \mathbf{b}(\mathbf{c})$, d, e (f), showing the maximal $\left[\mathrm{Ca}^{2+}\right]_{\mathrm{i}}$ change after restoring $\mathrm{Ca}^{2+}$ in bath. Mean $\pm \operatorname{SEM}(n=4$ for $\mathbf{c} ; n=5-10$ for $\mathbf{f})$ data are shown $(* p<0.05$; $* * p<0.01)$

One concern might be the stability of NO donors. The question is whether SNAP and DEA-NONOate applied to the cells could indeed increase NO concentration in cultured cells. In this regard, strict protocols were followed to preserve the activity of the NO donors. The same NO donor preparations relaxed aortic strips concentrationdependently, elicited NO rises in HEK293 cells, and inhibited TRPC6 via a cGMP-PKG pathway (Fig. 4). The data substantiate the competence of the NO donors in our experimental settings.

The data in our study further support the conclusion that the cysteine residues in the ion pore region of TRPC5 (cysteines 553 and 558) are involved in an extracellular disulfide bridge [23]. Such covalent bonding precludes availability of the cysteine residues for S-nitrosylation unless the bridge is broken by a reducing agent. Consistent with this conclusion, mutating the cysteines resulted in fully active channels that were unresponsive to lanthanide [23].

The observed inhibitory effect on an endothelial $\mathrm{Ca}^{2+}$ entry mechanism suggests the possibility for an effect of 
NO on a $\mathrm{Ca}^{2+}$ channel complex involving TRPC5. Such an inhibitory effect may have physiological importance as a negative feedback mechanism in the control of NO release. However, failure to observe stimulation or inhibition of overexpressed TRPC 5 by NO suggests that the endothelial effect did not occur through a direct action of NO on TRPC5.

Our results in TRPC5-over-expressing HEK293 cells and BAECs show some divergence from those of Yoshida et al. and others $[13,24]$. In additional experiments, we used the same composition of extracellular solution and TRPC5 clone as Yoshida et al. [24] but were unable to observe a stimulatory effect (Suppl. Fig. 5). The reason for the discrepancy in results is not clear. Possible complicating factors could include differences in HEK293 cell sources, BAEC isolation procedures, and cell culture conditions. Such factors may alter the expression or activity of certain cellular factors that may be required for an indirect action of SNAP. Another possibility is that a stimulating effect of SNAP on basal $\left[\mathrm{Ca}^{2+}\right]_{\mathrm{i}}$ of some HEK293 cells might enhance TRPC5 activity via $\mathrm{Ca}^{2+}$-dependent potentiation.

In summary, the study provides evidence against $\mathrm{NO}$ as a direct modulator of TRPC5 channels and against Snitrosylation as a mechanism for stimulation of TRPC5 channels in the absence of a reducing factor. The study does, however, suggest that NO may indirectly inhibit endogenous $\mathrm{Ca}^{2+}$-entry mechanisms involving TRPC5.

Acknowledgments We are grateful for support from Hong Kong RGC grant (CUHK477307, CUHK477408, and CUHK479109), Focused Investment Scheme of Chinese University of Hong Kong, and $\mathrm{Li} \mathrm{Ka}$ Shing Institute of Health Sciences. DJB research was funded by the Wellcome Trust and Overseas Research and University scholarships to PS. We thank Y. Mori for providing mTRPC5 and SNAP and for comments on the manuscript.

\section{References}

1. Beech DJ (2007) Canonical transient receptor potential 5. Handb Exp Pharmacol 176:109-123

2. Bicker G (2005) STOP and GO with NO: nitric oxide as a regulator of cell motility in simple brains. Bioessays 27:495-505

3. Cheng KT, Leung YK, Shen B, Kwok YC, Wong CO, Kwan HY, Man YB, Ma X, Huang Y, Yao X (2008) CNGA2 channels mediate adenosine-induced $\mathrm{Ca}^{2+}$ influx in vascular endothelial cells. Arterioscler Thromb Vasc Biol 28:913-918

4. Chung HT, Choi BM, Kwon YG, Kim YM (2008) Interactive relations between nitric oxide $(\mathrm{NO})$ and carbon monoxide $(\mathrm{CO})$ : heme oxygenase-1/CO pathway is a key modulator in NO-mediated antiapoptosis and anti-inflammation. Methods Enzymol 441:329-338

5. Dedkova EN, Blatter LA (2002) Nitric oxide inhibits capacitative $\mathrm{Ca}^{2+}$ entry and enhances endoplasmic reticulum $\mathrm{Ca}^{2+}$ uptake in bovine vascular endothelial cells. J Physiol 539:77-91

6. Hess DT, Matsumoto A, Kim SO, Marshall HE, Stamler JS (2005) Protein S-nitrosylation: purview and parameters. Nat Rev Mol Cell Biol 6:150-166
7. Ignarro LJ (2002) Nitric oxide as a unique signaling molecule in the vascular system: a historical overview. J Physiol Pharmacol 53:503-514

8. Jaffrey SR, Erdjument-Bromage H, Ferris CD, Tempst P, Snyder SH (2001) Protein S-nitrosylation: a physiological signal for neuronal nitric oxide. Nat Cell Biol 3:193-197

9. Jiang F, Gibson AP, Dusting GJ (2001) Endothelial dysfunction induced by oxidized low-density lipoproteins in isolated mouse aorta: a comparison with apolipoprotein-E deficient mice. Eur J Pharmacol 424:141-149

10. Jung S, Muhle A, Schaefer M, Strotmann R, Schultz G, Plant TD (2003) Lanthanides potentiate TRPC5 currents by an action at extracellular sites close to the pore mouth. J Biol Chem 278:35623571

11. Kwan HY, Huang Y, Yao X (2000) Store-operated calcium entry in vascular endothelial cells is inhibited by cGMP via a protein kinase G-dependent mechanism. J Biol Chem 275:6758-6763

12. Kwan HY, Huang Y, Yao X (2004) Regulation of canonical transient receptor potential isoform 3 (TRPC3) channel by protein kinase G. Proc Natl Acad Sci USA 101:2625-2630

13. Mottola A, Antoniotti S, Lovisolo D, Munaron L (2005) Regulation of noncapacitative calcium entry by arachidonic acid and nitric oxide in endothelial cells. FASEB J 19:2075-2077

14. Schaefer M, Plant TD, Obukhov AG, Hofmann T, Gudermann T, Schultz G (2000) Receptor-mediated regulation of the nonselective cation channels TRPC4 and TRPC5. J Biol Chem 275:17517-17526

15. Snyder SH (1994) Nitric oxide. More jobs for that molecule. Nature 372:504-505

16. Stamler JS, Toone EJ, Lipton SA, Sucher NJ (1997) (S)NO signals: translocation, regulation, and a consensus motif. Neuron 18:691-696

17. Strubing C, Krapivinsky G, Krapivinsky L, Clapham DE (2003) Formation of novel TRPC channels by complex subunit interactions in embryonic brain. J Biol Chem 278:39014-39019

18. Takahashi S, Lin H, Geshi N, Mori Y, Kawarabayashi Y, Takami N, Mori MX, Honda A, Inoue R (2008) Nitric oxide-cGMPprotein kinase $\mathrm{G}$ pathway negatively regulates vascular transient receptor potential channel TRPC6. J Physiol 586:4209-4223

19. Wei T, Chen C, Hou J, Xin W, Mori A (2000) Nitric oxide induces oxidative stress and apoptosis in neuronal cells. Biochim Biophys Acta 1498:72-79

20. Wong CO, Huang Y, Yao X (2010) Genistein potentiates activity of the cation channel TRPC5 independently of tyrosine kinases. Br J Pharmacol 159:1486-1496

21. Xu SZ, Zeng F, Boulay G, Grimm C, Harteneck C, Beech DJ (2005) Block of TRPC5 channels by 2-aminoethoxydiphenyl borate: a differential, extracellular and voltage-dependent effect. Br J Pharmacol 145:405-414

22. Xu SZ, Boulay G, Flemming R, Beech DJ (2006) E3-targeted anti-TRPC5 antibody inhibits store-operated calcium entry in freshly isolated pial arterioles. Am J Physiol Heart Circ Physiol 291:H2653-H2659

23. Xu SZ, Sukumar P, Zeng F, Li J, Jairaman A, English A, Naylor J, Ciurtin C, Majeed Y, Milligan CJ, Bahnasi YM, Al-Shawaf E, Porter KE, Jiang LH, Emery P, Sivaprasadarao A, Beech DJ (2008) TRPC channel activation by extracellular thioredoxin. Nature 451:69-72

24. Yoshida T, Inoue R, Morii T, Takahashi N, Yamamoto S, Hara Y, Tominaga M, Shimizu S, Sato Y, Mori Y (2006) Nitric oxide activates TRP channels by cysteine S-nitrosylation. Nat Chem Biol 2:596-607

25. Zeng F, Xu SZ, Jackson PK, McHugh D, Kumar B, Fountain SJ, Beech DJ (2004) Human TRPC5 channel activated by a multiplicity of signals in a single cell. J Physiol 559:739-750 